\title{
KEBIJAKAN FISKAL DALAM PERSPEKTIF ISLAM (BAITUL MAAL SEBAGAI BASIS PERTAMA DALAM PENDAPATAN ISLAM) Oleh: Sulaeman Jajuli*
}

\begin{abstract}
Abstraksi
Al-Daulah al-Islâmiyyah pertama kali dibentuk setelah Rasulullah $\mathbf{n}$ hijrah dari Makkah ke al-Madinah al-Munawarah dan menetapnya Rasulullah di Madinah dengan para sahabat $\mathbf{9}$.

Kaum Muhajirin sebagai pendatang dan kaum Anshor sebagai ahlulbait atau pemilik tempat telah mengikhlaskan rumah-rumah mereka untuk dijadikan sebagai tempat tinggal oleh para pendatang (kaum Muhajirin). Satu tahun setelah menetapnya kaum Muhajirin dan setelah bersatunya hati-hati kaum Muhajirin dan kaum Anshor, timbullah peperangan antara kaum Musyrikin Makkah dengan kaum Muslimin di Madinah. Kemenangan-kemenangan yang diraih kaum muslimin dalam peperangan terus berlanjut, klimaksnya kaum Muslimin banyak mendapatkan harta ghanîmah, sehingga menimbulkan pertentangan dan perselisihan dalam pembagiannya Adapun pada masa Nabi Muhammad, para shahabat yang telah menang dalam peperarangan, mereka berhak membawa harta ghanîmah ke rumah, maka timbullah berbagai pertanyaan; untuk siapa harta rampasan tersebut, milik siapa, bagaimana cara pembagiannya, tanah yang telah berhasil dikuasai, siapakah yang memiliki dan mengolahnya.

Dengan adanya berbagai macam pertanyaan dan permasalahan yang terjadi sekitar harta rampasan/ghanîmah, maka permasalahan tersebut memerlukan jawab-an dengan segera. Rasulullah dan para shahabatnya membuat sebuah lembaga untuk menampung harta yang telah dimiliki kaum muslimin khususnya setelah terjadi peperangan. Tempat penampungan harta tersebut dinamakan dengan Baitul maal. Baitul maal sebagai lembaga dan wadah tempat penyimpanan harta yang dimiliki masyarakat Muslim pertama kali diadakan dalam Islam.
\end{abstract}

Kata Kunci: Kebijakan Fiskal, Hukum Islam, Baitul Maal

\section{A. Pendahuluan}

Agama Islam yang dibawa Nabi Muhammad $\mathbf{n}$ adalah agama yang sempurna. Kesempurnaan Islam ditulis dan dijadikan pegangan bagi kaum msulimin dalam kitab al-Qur'an yang di dalamnya membahas tentang hukum-hukum ketuhanan, kehidupan manusia, akhlak bermuamalah dan lain sebagainya. Selain dalam kitab al-Qur'an dijelaskan pula dalam Sunnah Nabi Muhammad $\mathbf{n}$.

Al-Daulah al-Islâmiyyah pertama kali dibentuk setelah Rasulullah $\mathbf{n}$ hijrah dari Makkah ke al-Madinah al-Munawarah dan menetapnya Rasulullah di Madinah dengan para sahabat $\boldsymbol{9}$.

Kaum Muhajirin sebagai pendatang dan kaum Anshor sebagai ahlulbait atau pemilik tempat telah mengikhlaskan rumah-rumah mereka untuk dijadikan sebagai tempat tinggal oleh para pendatang (kaum Muhajirin). Satu tahun setelah menetapnya kaum Muhajirin dan setelah bersatunya hati-hati kaum Muhajirin dan kaum Anshor, timbullah peperangan antara kaum Musyrikin Makkah dengan kaum Muslimin di Madinah. Kemenangankemenangan yang diraih kaum muslimin 
dalam peperangan terus berlanjut, klimaksnya kaum Muslimin banyak mendapatkan harta ghanîmah, sehingga menimbulkan pertentangan dan perselisihan dalam pembagiannya. ${ }^{1}$

Artinya: "mereka menanyakan kepadamu tentang pembagian harta rampasan perang. Katakanlah: "Harta rampasan perang itu kepunyaan Allah dan Rasul', sebab itu bertaqwalah kepada Allah dan perbaikilah hubungan diantara sesamamu, dan ta'atlah kepada Allah dan Rasul-Nya jika kamu adalah orang-orang yang beiman”.

(QS.Al-Anfal:1)

Hal yang terjadi ketika harta ghanimah terkumpul, banyak para shahabat yang belum memahami dengan sepenuhnya tentang harta rampasan, karena mereka belum pernah mendapatkannya dan belum ada contoh sebelumnya. Pada masa Nabi Musa $\mathbf{O}$, ketika mereka mendapakan harta ghanimah, harta tersebut dibakar dan tidak boleh dikonsumsi atau diambil dan dipergunakan kembali. Adapun pada masa Nabi Muhammad, para shahabat yang telah menang dalam peperarangan, mereka berhak membawa harta ghanimah ke rumah, maka timbullah berbagai pertanyaan; untuk siapa harta rampasan tersebut, milik siapa, bagaimana cara pembagiannya, tanah yang telah berhasil dikuasai, siapakah yang memiliki dan mengolahnya.

Dengan adanya berbagai macam pertanyaan dan permasalahan yang terjadi sekitar harta rampasan/ghanîmah, maka permasalahan tersebut memerlukan jawab-

* Dosen Fakultas Ekonomi Islam Universitas Muhammadiyah Jakarta

1 Said Saad Marthon, al-Madkhol, hal. 93

2 Maksudnya: Harta rampasan perang itu menurut ketentuan Allah dan Rasul-Nya (al-Qur'an Terjemah DEPAG) an dengan segera. Rasulullah dan para shahabatnya membuat sebuah lembaga untuk menampung harta yang telah dimiliki kaum muslimin khususnya setelah terjadi peperangan. Tempat penampungan harta tersebut dinamakan dengan Baitul maal. Baitul maal sebagai lembaga dan wadah tempat penyimpanan harta yang dimiliki masyarakat Muslim pertama kali diadakan dalam Islam.

Pendirian Baitul maal dalam konsep Islam merupakan tempat pengumpulan harta yang sangat strategis, sehingga harta yang dikumpulkan selain dari ghanîmah juga sebagai tempat pengumpulan harta zakat, jizyah, fa'i, kharaz,'usyr dan sekaligus digunakan sebagai tempat pendistribusiannya. Dengan demikian harta yang telah terkumpul dapat disusun dengan baik, rapih dan dapat disalurkan dan dibagikan kepada ahlinya secara langsung dan tertib.

Rasulullah $\mathbf{n}$ sebagai kepala negara di al-Madinah adalah orang pertama memperkenalkan konsep baru di bidang keuangan pada abad ke-7 M. Cara yang dilakukan Rasulullah dalam pengumpulan harta tersebut adalah harta ghanîmah tersebut dikumpulkan terlebih dahulu dan kemudian dikeluarkan sesuai dengan kebutuhan negara.

Hasil pengumpulan itu adalah milik negara dan bukan milik pribadi/individu. Meskipun demikian para pemimpin negara/khalifah dapat menggunakannya untuk keperluan pribadi sesuai dengan kebutuhan hidup yang mereka jalani selama menjabat sebagai khalifah.

Semasa Rasulullah $\mathbf{n}$ masih hidup, masjid Nabawi sebagai pusat kegiatan dan aktifitas, masjid tersebut digunakan sebagai kantor pusat negara yang sekaligus menjadi tempat tinggal Rasulullah dan harta Baitul maal disimpan dalam rumahnya. Untuk 
harta ghanîmah yang berupa binatang, sesuai dengan alamnya ditempatkan di padang terbuka.

Seperti dalam sebuah hadits dikatakan bahwa:

"Beberapa orang dari suku Ukraina datang ke Madinah dan mereka merasa iklim di daerahnya tidak nyaman, maka Rasulullah $\mathbf{n}$ mengijinkan mereka untuk pergi mengembalakan unta tersebut yang diambil dari hasil zakat. Dan di sana mereka minum susu unta serta menggunakan air seni unta untuk dijadikan sebagai obat. Tetapi mereka kemudian berbuat curang kepada Rasulullah dengan membawa unta ke rumahnya. Rasulullah $\mathbf{n}$ kemudian mengirimkan orang untuk menangkap mereka dan membawanya ke hadapan beliau. (H.R. Abu Daud).

Dengan demikian orang yang pertama kali membuat konsep keuangan negara adalah Rasulullah $\mathbf{n}$, uang tersebut diperoleh kaum muslimin dari hasil zakat atau setelah para shahabat mengikuti peperangan/berjihad yang kemudian disalurkan sesuai kebutuhan negara. Dari rakyat untuk negara dan dipergunakan oleh negara sesuai kebutuhan negara.

\section{B. Pengertian, Landasan Hukum, dan Sejarah Baitul Mal.}

Baitul maal berasal dari dua suku kata yaitu al-bait dan al-mâl (البيت و المال). Secara harfiah bermakna rumah tangga dan harta $^{3}$ atau perbendaharaan harta umat. Fungsi utamanya adalah sebagai gudang pengumpulan dan pngeluaran pendapatan negara. Kalimat Baitul maal sekarang sudah diserap menjadi bahasa Indonesia yang dipergunakan dalam perbankan.

3 Mahmud Yunus, Kamus Arab Indonesia, Jakrta, PT. Hida Karya Agung, 1990, hal. 74 dan hal.409
Baitul maal adalah tempat yang dikhususkan untuk mengumpulkan dan menjaga harta kekayaan kaum muslimin, yaitu sebuah institusi yang bertanggung jawab atas pemeliharaan public property (harta milik umum), berikut proses alokasi harta (dana) kepada yang berhak. ${ }^{4}$

Baitul maal adalah lembaga keuangan negara yang bertugas menerima, menyimpan, dan mendistribusikan uang negara sesuai dengan ketentuan syari'at. Baitul maal dapat disamakan dengan kas negara yang ada dewasa ini. ${ }^{5}$ Jadi Baitul maal memiliki makna sebagai lembaga keuangan dan tempat dikumpulkannya harta untuk dijaga yang bertanggung jawab dalam pemeliharaannya adalah orang yang dipercaya. Setelah harta Baitul maal terkumpul maka harta itu didistribusikan kembali sesuai dengan undang-undang dan ketentuan syari'at yang berlaku.

Abu al-A'la al-Maududy sebagai reformis dalam pemikiran serta pembaharuan yang berasal dari Pakistan menyatakan bahwa: "Baitul maal merupakan lembaga keuangan yang dibangun atas landasan syari'at. Oleh sebab itu pengelolaannya harus sesuai dengan syari'at Islam". Menurutnya pula, "Baitul maal adalah amanat Allah $\square$ dan masyarakat Muslim, karenanya tidak diizinkan memasukan sesuatu ke dalamnya dengan mendistribusikan sesuatu dari nya dengan cara yang berlawanan dengan apa yang ditetapkan dalam syari'at". ${ }^{6}$

Baitul maal merupakan lembaga keuangan, cara pemasukan dan pengeluarannya sesuai dengan ketentuan

Said Sa'ad Marthon, al-Madkhol, hal. 95

Abdul Aziz Dahlan, Ensiklopedia Hukum Islam, Jakarta, PT Intermasa, 1996, hal. 901.

6 Abu A'la al-Maududi, the Islamic Movemen: The Dynamics of Values, Power and Change. Leicestyer .U.K: The Islamic Poundation, hal. 47 
syari'at yang telah digariskan dalam alQur'an dan as-Sunnah. Jika keluar dari jalur syari'at Islam, maka harta yang ada di dalamnya akan habis dan pemasukan yang ada tidak bisa ditentukan kehalalan dan keharamannya. Dengan berlandaskan hukum yang benar, Baitul maal akan tampak lebih mudah dalam pengecekan, pemasukan dan pengeluaran yang digunakan untuk kepentingan negara.

Orang-orang yang dipercaya dalam pendistribusian harta Baitul maal harus sesuai dengan ketentuan syari'at, berkarakter syari'at, bergaul sesuai syari' at dengan tidak mencuri, menipu, berbohong atau sifat lainnya yang dilarang dalam ajaran Islam. Sebab dalam Islam ketika seseorang mengelola sesuatu yang bersangkutan dengan hajat kehidupan manusia, maka ia disyaratkan harus sesuai dengan potensi yang dimilikinya dan profesional dalam melakukannya. Bila tidak, maka kehancurannya sudah berada di ambang pintu. Karenanya Baitul maal adalah amanat Allah dan amanat masyarakat muslim yang tidak sembarangan orang bisa menggunakan dan mengelolanya.

Baitul maal pertama kali ada pada masa Rasulullah $\mathbf{n}$ dan khalifah Abu Bakar. Amirul Mukminin Umar ibn alKhaththab melanjutkan perjalanan dua shahabat sebelumnya. Satu hal yang perlu dicatat dalam Baitul maal pada masa Amirul Mukminin Umar ibn al-Khaththab adalah lebih terfokus dan lebih tertib, yang mana sebelumnya Baitul maal hanya disimpan dalam rumah Rasulullah dan Khalifah Abu Bakar. Pada masa Umar Baitul maal disimpan dalam suatu wadah/tempat tertentu yang disebut dengan lembaga keuangan atau al-dîwân almâliyah.
Baitul maal pertama kali berdiri sebagai lembaga keuangan, setelah Rasulullah $\mathbf{n}$ dan para shahabat $\mathbf{9}$ memenangkan perang Badar al-Kubra pada tahun ke-2 H. Harta ghanîmah (harta rampasan perang) yang didapatkan kaum muslimin awalnya menimbulkan pertentangan dan perselisihan dalam pembagiannya, maka Allah $\boldsymbol{\square}$ berfirman:

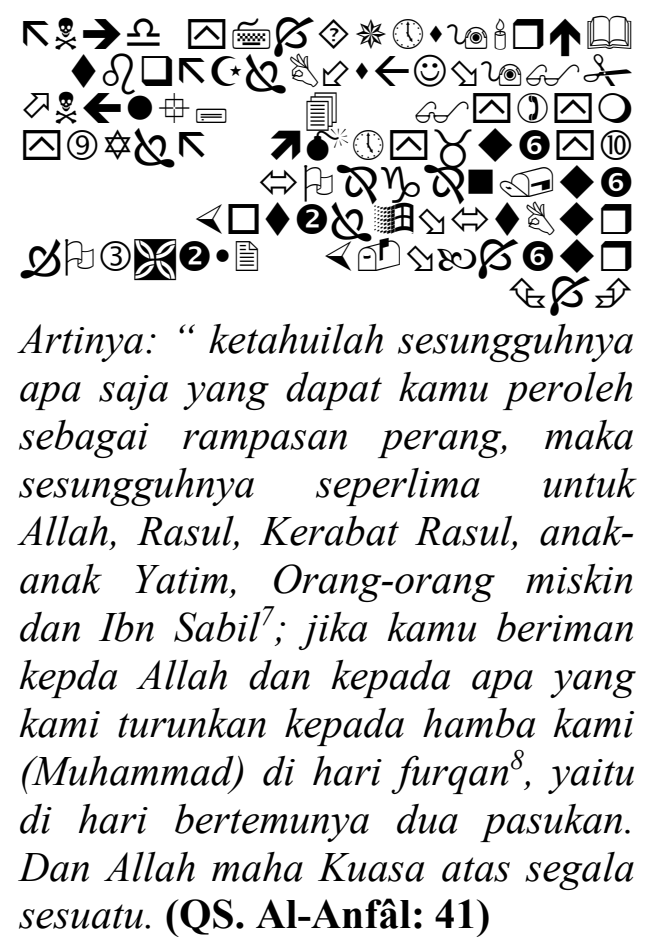

7 Maksudnya seperlima dari harta ghanimah itu dibagikan kepada:

a. Allah dan Rasul-Nya

b. Kerabat Rasul (Banu Hasyim dan Banu Muthallib)

c. Anak Yatim

d. Orang Miskin

e. Ibnu sabil sedang empat perlima dari ghanimah itu dibgaikan kepda mereka yang ikut berperang.

8 Furqon artinya pemisah antara hak dan bathil. Makna hari furqon adalah hari jelasnya kemenangan orang Islam dan kekalahan orang kafir, yaitu hari bertemunya dua pasukan di peperangan badar, pada hari jum'at tanggal 17 Ramadhan tahun ke dua hijriyyah. Sebagian mufassirin berpendapat bahwa ayat ini mengisyaratkan kepda hari permulaan turunnya al-Qur'an al-Karim pada malam 17 Ramadhon. (al-Qur'an dan Terjemahnya, DEPAG) 
Setelah diturunkan ayat ini ada kejelasan tentang pembagian harta rampasan perang, seberapa banyak harta yang harus diambil dan diberikan untuk Allah dan Rasul-Nya untuk dimasukan ke dalam Baitul maal dan sisa dari harta ghanîmah lainnya untuk mereka yang ikut berjihad. Rasulullah membagi harta ghanîmah tersebut dan diberikan kembali untuk kaum muslimin dengan menggunakan pembagian al-khumus (1/5), setelah itu turunlah ayat yang menyatakan cara pembagian harta ghanîmah.

Dengan demikian jelaslah bagi kaum muslimin, pendapatan yang diraih dalam peperangan berupa harta ghanîmah, diberikan terlebih dahulu kepada Rasulullah dan diketahui berapa harta yang harus diambil oleh mereka. Harta yang diberikan kepada kaum muslimin sebagai pendistribusian selanjutnya disimpan dalam Baitul maal yang kemudian akan dibagikan kembali untuk kepentingan kaum muslimin yang tidak mampu dan tidak ikut berperang karena udzur syar'i.

Rasulullah dan para shahabat dalam peperangan selanjutnya terus meraih kemenangan, sehingga daerah kekuasaan Islam semakin berkembang. ${ }^{9}$ Rasulullah sebagai Kepala negara, Pemimpin dibidang hukum, Panglima perang, Qhodi besar atau Mufti, Pemimpin, Penanggung jawab dari keseluruhan administrasi, tidak mendapatkan gaji sedikitpun dari negara atau dari rakyat, Rasulullah hanya mendapatkan sesuatu yang umumnya didapatkan oleh orang lain berupa makanan biasa. Dengan adanya pembagian harta ghanîmah yang merata dan adil, maka Rasulullah mendapatkan sedikit bagian harta tersebut sesuai dengan ketentuan Allah dan Rasul-

9 Isma'il Pamungkas, Seri Riwayat Nabi, Bandung: PT Remaja Rosda Karya, 2000, Cet. III, bag. III, hal.11
Nya dan walupun ia berhak mendapatkan harta ghanimah, tetapi Rasulullah tidak pernah mengambil harta ghanîmah secara berlebihan apalagi memakannya.

Baitul maal yang terjadi pada masa Amirul Mukminin Umar ibn al-Khaththab telah mengalami kemajuan yang pesat, karenanya tidak heran seandainya Umar menjadikan Baitul maal sebagai wadah yang berdiri sendiri dan dijadikan sebagai tempat untuk menyimpan dan menyalurkan harta.

Hal yang terjadi dalam pendistribusian harta Baitul maal pada masa Umar adalah dengan pembagian pos-pos kerja, gaji para karyawan yang ikut dan tidak ikut berperang. Sesuai dengan konsep hukum Islam bahwa harta ghanîmah itu adalah hak bagi seseorang yang ikut berperang dan beliau sah mengambil harta tersebut setelah adanya pehitungan dari khumus (seperlima untuk Allah dan Rasul-Nya/kepentingan kaum muslimin).

Untuk orang yang tidak ikut berperang dikarenakan 'udzur, perempuan, masih anak-anak, atau sudah pensiun dalam perangan karena sudah lanjut usia (sudah tua), maka Amirul Mukminin Umar ibn alKhaththab memberikan gaji kepada mereka dari harta Baitul maal dan bagi yang sudah tua diberikan dana pensiun yang diambil dari Baitul maal.

Properti Baitul maal dianggap sebagai 'harta kaum muslimin', sedangkan khalifah dan amil-amilnya hanyalah pemegang kepercayaan. Jadi, menjadi tanggung jawab negara menyediakan tunjangan yang berkesinambungan untuk janda, anak yatim, anak terlantar, membiayai penguburan mayat untuk orang miskin, membayar utang orang yang bangkrut, membayarkan uang diyat untuk kasus-kasus tertentu seperti membayar diyat prajurit muslim yang membunuh 
seorang Kristen demi menyelamatkan nyawanya. ${ }^{10}$ Sangat besar dan sangat bermanfaat harta yang dikumpulkan dalam Baitul maal, harta yang dikumpulkan didistribusikan kepada yang mereka yang berhak karena didasarkan atas saling keterpercayaan anatar umat Muslim.

Selama menjabat sebagai Amirul Mukminin, Umar Ibn al-Khaththab memelihara Baitul maal secara hati-hati, menerima pemasukan dari yang halal sesuai dengan syariat Islam dan mendistribusikannya kepada yang berhak menerima. Dalam sebuah pidatonya yang dicatat oleh Imam Ibnu Katsir tentang hak seorang khalifah dalam Baitul maal, Umar berkata: "Tidak dihalalkan bagiku dari harta milik Allah ini melainkan dua potong pakaian musim panas dan musim dingin serta uang yang cukup untuk kehidupan sehari-hari layaknya seperti orang biasa kebanyakan kaum muslimin". ${ }^{11}$

Umar ibn al-Khaththab a sangat berhati-hati dan sangat mulia perilaku dan akhlak yang dilakukannya. Karena kehawatiran Umar dengan harta dalam Baitul maal sampai baju yang dimilkinya hanya pakaian sederhana yang sering digunakan masyarakat biasa. Umar tidak pernah menggunakan pakaian kebesaran layaknya para raja yang ada di Persia maupun di Romawi, tapi cukup dengan dua potong pakaian ketika musim panas dan musim dingin.

\section{Sumber Utama Pemasukan Baitul Maal.}

Berbeda dengan kas negara pada zaman sekarang, harta pemasukan pada

10 Khussed Ahmad Farook, Hazrat Umar ke Sarkari, Nadwatul Musanifeen, Delhi. Hal. 28

11 Jaribah bin Ahmad al-Haritsi, al-Fiqh alIqtishâdi li Amiri al-Mukminîn Umar ibn al-alKhaththab, (terjmh.Asmuni Solihan Zmakhsari), Jakarta: Khalifa, 2006, hal. 676 lembaga Baitul maal diambil dari zakat, pajak, hasil dari barang-barang tambang, perusahaan-perusahaan lokal dan manca negara $^{12}$. Pada masa Umar pemasukan itu diambil dari harta zakat, ghanimah, fa'i, kharaj, jizyah, dan 'usyr.

\section{Zakat (الزكاة)}

Makna zakat secara bahasa berarti tumbuh (al-numuw) dan bertambah (alziyadah). Makna lain dari zakat secara etimologi adalah suci, dalam artian suci dari dosa dan kemaksiatan. Secara syar'i zakat adalah sedekah tertentu yang diwajibkan dalam syariah terhadap orang kaya dan diberikan kepada orang yang berhak menerimanya. ${ }^{13}$ Istilah lain secara syara zakat adalah hak yang wajib dikeluarkan dari harta ${ }^{14}$.

Zakat merupakan salah satu rukun islam yang lima, kalimat zakat sering bersanding dengan kalimat shalat dalam alQur'an, artinya betapa pentingnya kewajiban mengeluarkan zakat seperti kewajiban melaksanakan shalat. Dalam alQur'an yang digandengkan dengan kalimat shalat terdapat 82 tempat.

Zakat pertama kali diwajibkan tidak ditentukan kadar dan jumlahnya, tetapi hanya diwajibkan untuk memenuhi kebutuhan fakir dan miskin. Namun kewajiban membayar zakat dengan kadar dan nisab itu ditentukan ketika Rasulullah n hijrah ke Madinah.

Pada masa Amirul Mukminin Umar bin al-Khaththab a pendapatan zakat sebagai pendapatan negara sangat melimpah. Umar dengan kebijakannya telah

13 Sa'id Sa'ad Marthon, al-Madkhal fi al-Fikr alIslam. Hal. 105

14 Wahbah al-Zuahayly, al-Fiqh al-Islamy Adilatuh, (terjmah:Agus Effendi) Bandung, PT. Remaja Rosdakarya, 2000, cet. V, hal. 82 
menjadikan harta zakat sebagai pendapatan utama. Setelah khalifah Abu Bakar a memerangi orang-orang yang enggan membayar zakat, pendapatan negara dari zakat bertambah secara signifikan. Umar yang diangkat menjadi Amirul Mukminin telah mengeluarkan fatwa sebagai kebijakannya mengenai zakat.

Kebijakan-kebijakan yang dilakukan Umar terhadap harta zakat adalah :

a. Zakat barang-barang perniagaan,

b. Zakat mata uang emas dan perak,

c. Zakat binatang ternak,

d. Zakat sayur-sayuran dan buahbuahan.

e. zakat madu yang dijual bukan unutk dikonsumsi.

f. zakat kuda yang diperjual belikan. ${ }^{15}$

\section{Harta Ghanîmah atau al-Anfâl} (الغيمة أو الأنفال)

Harta ghanîmah secara etimologi berari rampasan perang ${ }^{16}$ atau harta yang diambil masyarakat Muslim dalam sebuah peperangan dengan bentuk yang syah dan dibolehkan dalam agama (halal). ${ }^{17}$ Harta ghanîmah disebut pula dengan al-Anfâl, alNuhbah dan al-Salab. Kata al-Anfal terdapat dalam al-Qur'an Surat al-Anfâl ayat pertama berbunyi:

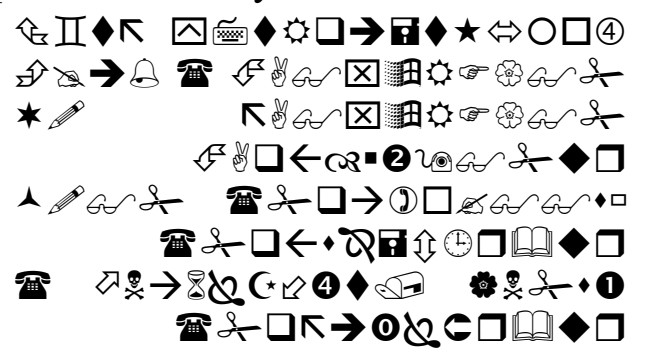

15 Muhammad Abdul Aziz al-Halawi, al-Fatawa wa al-'Aqidah Amirul Mukminin Umar ibn alKhaththab a, (terjmh. Zubeir Suryadi Abdullah) 2003, Surabaya, Risalah Gusti, cet II, hal. 96-116

16 Attabik 'Ali, Kamus al-Ashri, Yogyakarta, Multi karya, cet. VIII, hal. 1361

17 Ibrahim Musthafa, al-Mu'jam al-Washith, alMaktabah al-Islamiyyah, Istanbul Turki.

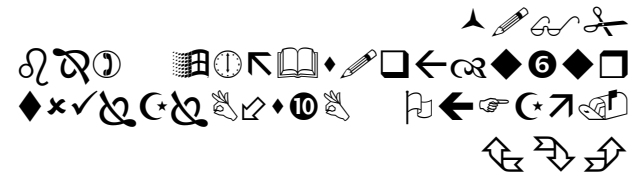

Artinya: "Mereka menanyakan kepadamu tentang pembagian harta rampasan perang. Katakanlah: "harta rampasan perang itu kepunyaan Allah dan Rasul ${ }^{18}$, sebab itu bertaqwallah kepada Allah dan perbaikilah hubungan diantara sesamamu, dan ta'atlah kepada Allah dan Rasul-Nya, jika kamu adalah orang-orang yang beiman”.

(QS.Al-Anfâl:1)

Jadi jelaslah bahwa harta ghanimah itu ada dalam Islam dan harta tersebut sah untuk dipakai setelah ada pembagian untuk Allah dan Rasul-Nya yaitu 1/5 bagian. Pembagian harta ghanîmah menurut Amirul Mukminin Umar Ibn al-Khaththab adalah hanya diperuntukan bagi mereka yang ikut berperang, "maka untuk yang menggunakan kuda diberikan 3 bagian dan yang berjalan kaki hanya satu bagian."19

Harta ghanîmah atau al-anfâl adalah harta yang diperoleh dari musuh-musuh Islam melalui peperangan dan pertempuran. Dihalalkannya harta ghanîmah sesuai dengan petunjuk Allah dalam al-Qur'an surat al-Anfâl ayat 69 yang berbunyi:

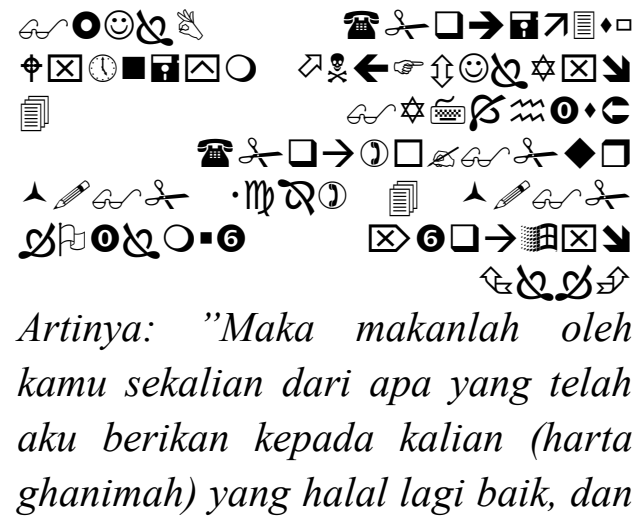

18 Maksudnya: Harta rampasan perang itu menurut ketentuan Allah dan Rasul-Nya

19 Abu bakar Jabir al-Jazairy, Minhaj al-Muslim, maktabah al-ulum wa al-hukum, al-Madinah alMunawwarah, hal. 297 
bertaqwalah kamu kepada Allah. Sesungguhnya Allah Zat Maha

Pengampun lagi Maha Penyayang”. (Q.S. al-Anfal/8:69)

Dengan diturunkannya ayat ini jelaslah bahwa hukum harta ghanimah adalah harta yang halal untuk dimakan dan halal juga untuk dikonsumsi. Harta tersebut selain halal juga baik. Artinya harta ghanîmah baik dalam bentuk fisiknya juga halal dalam pemakaiannya.

Setelah menjelaskan kehalalan harta ghanîmah, kemudian Allah memerintahkan kepada mereka yang mengkonsumsi harta tersebut agar bertaqwa kepada Allah. Sebab boleh jadi ketika seseorang memiliki harta yang banyak dan melimpah mereka enggan kembali berjihad dan merasa hawatir kalau harta tersebut habis digunakan untuk berjihad, yang biasa terjadi pada diri manusia adalah mereka takut hidupnya jatuh miskin atau takut mati ketika harta terus bertambah banyak. Maka Allah mengatakan dalam al-Qur'an surat al-Anfâl ayat 69 "Bertaqwalah kamu kepada Allah", karena taqwalah obatnya penyakit hati dan taqwa sebagai obat bagi mereka yang takut akan mati.

\section{Harta Fa'i (الفيء)}

$F a ' i$ secara etimologi berati pajak. ${ }^{20}$ Secara epistimologi $f a$ ' $i$ berarti harta yang diperoleh dari musuh Nonmuslim bukan dari peperangan, tetapi orang-orang Nonmuslim memberikannya secara suka rela dan ikhlas (tanpa ada unsur paksaan dari mereka setelah adanya perjanjian dengan pemerintah Islam). ${ }^{21}$ Termasuk kedalam harta $f a ' i$ adalah harta jizyah (pajak yang di pungut dari Non muslim).

20 Atabik Ali, Kamus, hal. 1413

21 Departemen Agama R.I, Proyek pengadaan kitab Suci al-Qur'an, Jakarta, 1983/1984 hal.61
Dan kharaj (pajak tanah), hibah, harta warisan kaum Dzimmi yang tidak mempunyai ahli waris dan sebagainya. 
Imam al-Mawardi mengatakan:

"Harta fa'i termasuk hak Baitul maal karena pendistribusiannya tergantung dari pertimbangan dan ijtihad pemimpin negara. Hal ini berbeda dengan harta ghanimah yang mana didapatkannya setelah terjadi peperangan dan harta itu adalah hak para pejuang yang ikut berperang". ${ }^{22}$

Akan tetapi Imam Abu Hanifah dan Imam Malik memasukan harta ghanîmah sebagai salah satu sumber Baitul maal. Menurut dua Imam Mazhab fikih: "Sebagian harta ghanîmah dapat dijadikan wakaf sebagai kepentingan umum yang bermanfaat". ${ }^{23}$

Allah membolehkan pengambilan harta $f a$ ' $i$ ini dan hukumnya adalah halal. Seperti difirmankan dalam al-qur'an surat al-Hasyr/59:6-7

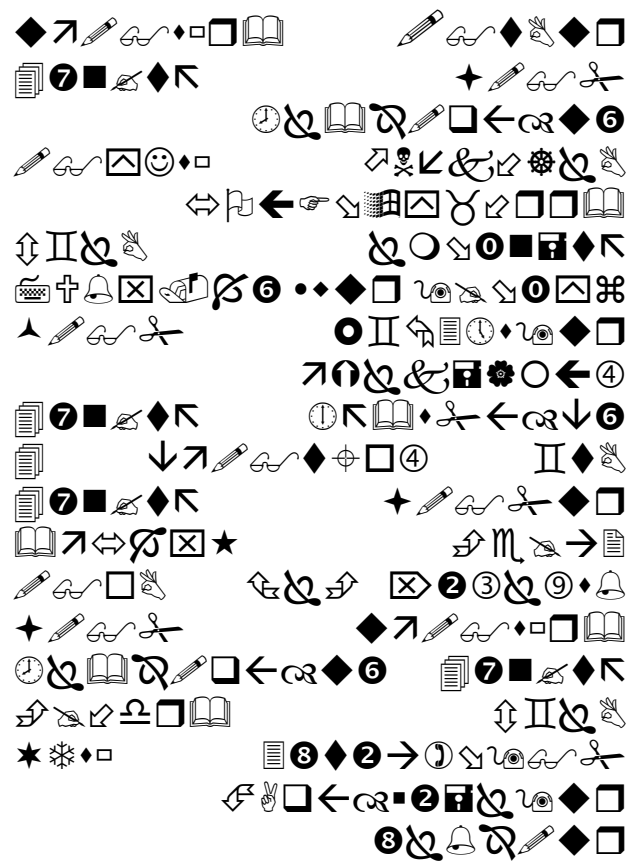

22 Imam Taqiyuddin Abi Bakar bin Muhammad alHusaini, Kifayatu al-Akhyar fi Halli Ghayati alIkhtisor, Darul al-Kutub, Surabaya, Juz II, hal.214

23 Muhammad Baltaji, al-Manhaj li Umar ibn alAl-Khaththab fi at-Tasyri', (terjmh. Masturi Ilha), Khalifa, Jakarta, 2005, hal.170

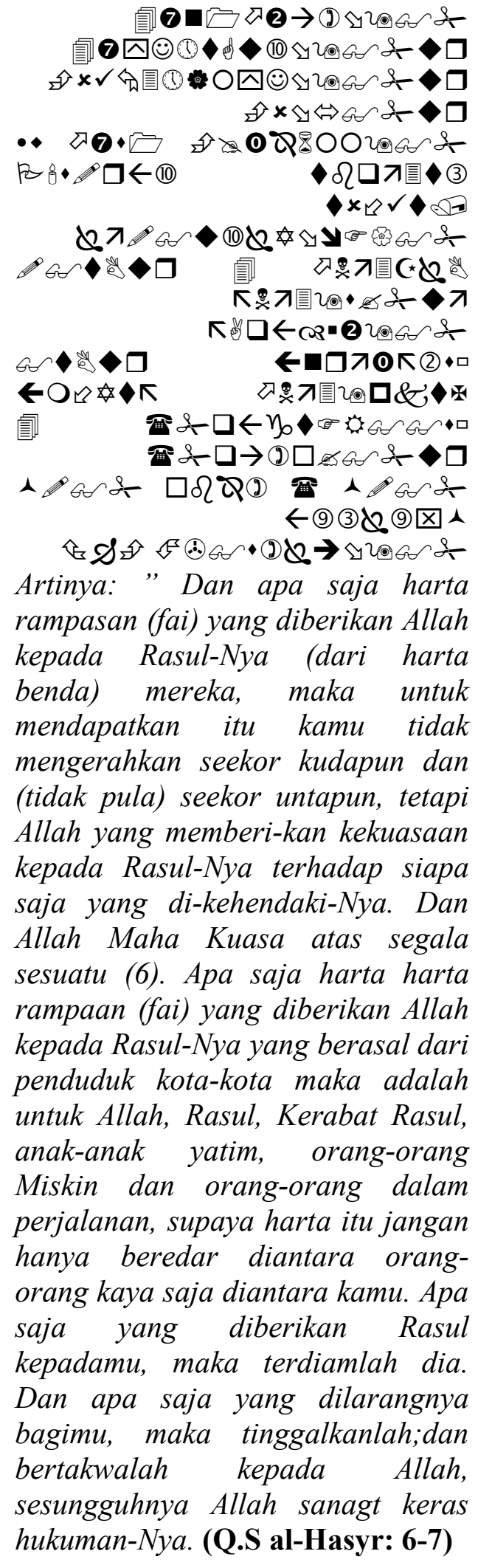

Penjelasan ayat ini telah dijelaskan dalam salah satu kitab tafsir bahwa harta $f a$ ' $i$ didapatkan bukan dari peperangan yang mengerahkan senjata, kuda dan unta tapi 
harta itu adalah harta murni yang didapatkan dari orang-orang kafir, ketentuan pembagiannya adalah untuk Allah dan Rasul-Nya. Sebagaimana dikatakan dalam kitab tafsir Ibn Katsir, " $F a$ ' $i$ adalah harta yang diambil dari orangorang kafir dengan tanpa ada peperangan didalamnya dan tanpa pengerahan kuda atau unta". ${ }^{24}$

Sayyid Quttub mengatakan bahwa: "Ayat-ayat ini menerangkan tentang hukum fa'i dan hukum-hukum yang semisal dengannya. Ayat ini menjelaskan tentang hukum fa'i secara terperinci, ia memberikan penjelasan tentang sebab pembagian dan meletakan kaidah besar dalam sistim ekonomi dan sosial dalam masyarakat muslim". ${ }^{25}$

Jadi jelaslah harta $f a^{\prime} i$ adalah harta halal untuk umat Islam karena al-Qur'an telah menjelaskan kehalalan harta tersebut, diperbolehkan mengambil dan mengkonsumsinya, harta tersebut didapatkan dari orang-orang kafir tanpa ada paksaan dan kekerasan. Dalam pendistribusiannya ketika pada masa Rasulullah $\mathbf{n}$ adalah sebagian untuk Rasulullah $\mathbf{n}$, untuk kerabatnya dari bani Hasyim dan bani Muthalib, untuk Yatâmâ, Masâkin dan Ibnu Sabîl. Termasuk kedalam harta $f a$ ' $i$ adalah harta jizyah, kharaj, hibah dan harta warisan dan orang kafir Dzimmi yang tidak mempunyai ahli waris dan sebagainya. Harta $f a^{\prime} i$ tidak didapatkan dari akibat peperangan.

\section{4. al-Kharaj (الخرج)}

Hal lain yang diambil untuk Baitul maal selain dari hasil peperangan adalah

24 Isma'il Ibn Katsir, Mukhtasar Tafsir Ibn Katsir, Tahqiqi, Muhammad Ali Ashobuny, jilid 3, Hal. 472

25 Sayyid Quttub, Tafsir Fi Zilal Qur'an, (terjm. As'ad Yasin dkk) Jakarta: Gema Husni, 2004, Hal.322
Kharaj. Kharaj artinya bea, pajak dan belasting ${ }^{26}$, akar katanya adalah KharajaYakhruju khurujan. Artinya keluar atau sejenis pajak yang dibebankan atas tanah yang dimiliki oleh nonmuslim. ${ }^{27}$ Dalam istilah syar'i kharaj adalah pajak yang dikenakan atas tanah yang ditaklukan oleh pasukan Islam ${ }^{28}$. Makna lain dari kharaj adalah pajak bumi yang diwajibkan oleh kepala negara kepada masyarakat yang mengadakan perjanjian perlindungan negara. ${ }^{29}$

Pada mulanya tanah kharaj adalah harta ghanîmah berupa tanah yang diambil melalui peperangan. Pada masa Amirul Mukminin Umar ibn al-Khaththab a harta ghanimah dibagi kedalam dua bagian, harta bergerak dan harta tidak bergerak. Termasuk ke dalam kategori harta bergerak seperti kuda, barang-barang perkakas yang dibawa perang, alat-alat perang dan lainnya. Bagian kedua, harta tidak bergerak yang berupa tanah.

Pada masa Amirul Mukminin Umar ibn al-Khaththab a, harta ghanimah cukup luas karena adanya perluasan da'wah dan tanah tersebut dinamakan tanah sawad (tanah pertanian yang subur) Karena tanah tersebut terletak di tempat yang sangat subur, khususnya di Irak yang terdapat banyak tanah subur. Harta kharaj di ambil Amirul Mukminin karena telah ditaklukan daerahnya oleh tentara Muslim. Umar berpendapat bahwa untuk kemaslahatan bersama tanah yang dikuasai itu tidak dibagi-bagi demi kepentingan umum, termasuk lapangan untuk pasukan perang.

\footnotetext{
Mahmud Yunus, Kamus, hal. 115

27 Irfan Mahmud Ra'ana, Economic System Under Umar Greath(terjmh, Mansuruddyn Djoely), Pustaka Firdaus, Jakarta, 1997, hal.118

28 M. Rawwas Qal-Haji, Ensiklopedi, hal. 85

29 Ibid., hal. 86

29 Abdul Aziz Dahlan, Ensiklopedia, hal. 901
} 
Amirul Mukminin Umar ibn alKhaththab a telah menertibkan admisnistrasi kharaj. Dalam sejarah dicatat bahwa Umar ibn al-Khaththablah orang pertama yang mendirikan dewan administrasi tanah.

Gagasan yang dilakukan Amirul Mukminin Umar ibn al-Khaththab a diawali dari pengiriman pajak tanah dari Bahroin yang dibawa oleh gubernur $\mathrm{Abu}$ Hurairah a. Penggunaan uang tersebut dimusyawarahkan, Khalid Ibn Walid memberikan usulan kepada Amirul Mukminin Umar ibn al-Khaththab a agar mendirikan diwan Kharaj dan Umar menyetujuinya. ${ }^{30}$

Ketika berlangsung penaklukan besarbesaran pada masa Amirul Mukminin Umar ibn al-Khaththab $\mathbf{a}$, hak milik penduduk asli dibiarkan tidak terganggu sedikitpun, tanah mereka diolah dengan sendirinya oleh penduduk asli dengan syarat mereka harus membayar kharaj. Setelah penaklukan Islam semakin merambah dan meluas seperti Irak, Suriah, Mesir, kondisi dan sistim perpajakan berbeda-beda. Para raja dan tuan tanah yang mempunyai pengaruh di daerahnya terpaksa meninggalkan negerinya masing-masing atau mereka kehilangan kekuasaan. Akhirnya tanah tersebut tidak bertuan dan tidak ada yang memilikinya, Umar-pun menyita tanah tersebut dan dinyatakan bahwa tanah itu adalah milik umat. Kondisi tanah atau bumi dilihat dari kewajiban pembayarannya terhadap pajak terbagi kepada dua bagian:

a. Bumi yang pemiliknya sudah masuk Islam, tanah yang seperti ini sah kepunyaan orang muslim dan tidak ada kewajiban kharaj di dalamnya.

b. Bumi perdamaian yaitu setiap bumi yang penduduknya mengadakan perjanjian perdamian dengan negara Islam agar tanah mereka itu tetap menjadi milik mereka dan Islam tidak mengganggu gugatnya tetapi mereka diwajibkan membayar kharaj.

Pada masa Bani Umayyah aturan kharaj diperoleh lebih rinci, seperti halnya pada masa khalifah Abdul Malik, khalifah ini memberlakukan pengawasan yang ketat untuk keperluan perpajakan tanah sampai ia membuat sebuah dewan khusus yang di sebut "Dar al-Istikhroj" (tempat pengelolaan pajak).

Pada masa Bani Abbas pengawasan harta kharaj lebih ditingkatkan, sampai khalifah Harun al-Rosyid meminta kepada Abu Yusuf untuk membuatkan sebuah kitab yang berisi undang-undang negara tentang masalah kharaj; tentunya setelah selesai penulisan buku tersebut, di dalamnya membahas selain masalah kharaj juga memuat tentang aturan-aturan, pedoman, penarikan dan kadar pajak tanah. Inti dari kitab tersebut adalah merupakan hasil dari fatwa atau ijtihad Amirul Mukminin Umar ibn al-Khaththab $\mathbf{a}^{31}$.

Adapun cara yang digunakan dalam penarikan kharaj pada masa Amirul Mukminin Umar ibn al-Khaththab a terbagi kedalam dua bagian:

a. Muqassamah. Sistim yang dipungut pada sistim Muqassamah ini ditetapkan berdasarkan hasil dari porsi tanah tersebut sepertiga (1/3) atau setengahnya (1/2) ketika selesai kali panen yang harus diserahkan kepada Baitul maal.

b. Wazîfah. Kewajiban yang harus dibayar dari pemilik tanah jika telah

30 Muhammad Baltaji, al-Manhaj li Umar, hal.429

31 Abdul Aziz Dahlan, Ensiklopedia, hal. 901 
lewat satu tahun dengan ketetapan yang berlaku. ${ }^{32}$

Menurut Abu Yusuf, Kharaj ke dua ini diambil berbeda-beda menurut hasilnya. Contoh untuk kebun kurma 10 dirham setiap jaribnya $(1$ jarib $=60$ hasta, 1 hasta $=1 \mathrm{~m}$ ), untuk kebun tebu 6 dirham setiap jaribnya, untuk sayur-sayuran 5-10 dirham satu jaribnya, sedangkan untuk tanaman gandum sebanyak 4 dirham satu jaribnya. Tarif kharaj untuk produksi tanaman baru dikenakan 8 dirham dalam setiap jaribnya. $^{33}$

Dengan demikian tanah kharaj adalah tanah yang diambil setelah terjadinya peperangan. Tanah kharaj adalah harta ghanimah berupa tanah yang diolah oleh penduduk asli yang telah tunduk kepada pemerintah Islam dan hasilnya dibagi berbeda-beda menurut hasilnya. Pada masa sekarang tanah kharaj dikatakan sebagai pajak tanah, namun hasil dari harta tanah kharaj diberikan kepada penduduk asli yang memilki tanah dan untuk pemerintah.

\section{Harta Jizyah (الجزية)}

Kata Jizyah berasal dari kata jazâyajzi (جزى-يجزي-جزية ) yang berarti balasan. ${ }^{34}$ Kata jizyah juga diartikan dengan al-Dharibah bermakna upeti pajak. $^{35}$ Menurut istilah syara' makna jizyah diartikan dengan sejumlah mata uang yang terpikul pada pundak orang yang berada di bawah tanggungan kaum muslimin dan

32 Muhammad Qal'ahji, Mausu'atu al-Fiqhu Umar Ibn Al-Al-Khaththab, (terjmh: M. Abdul Mujib), PT Jakarta, Raja Grafindo Persada, 1999, cet. I, hal.332

33 Abu Yusuf, al-Kharaj, Cairo, Mathba'ah asSalafiah, 1982, Cet.III, hal. 43

34 Ibrahim Musthafa, Al-Mu'jam, hal. 120

35 Attabik Ali, Kamus, hal. 673 melakukan perjanjian dengan kaum muslimin dari ahli kitab. ${ }^{36}$

Landasan hukum jizyah adalah alQur'an Surat at-Taubah/9 ayat 29 yang berbunyi:

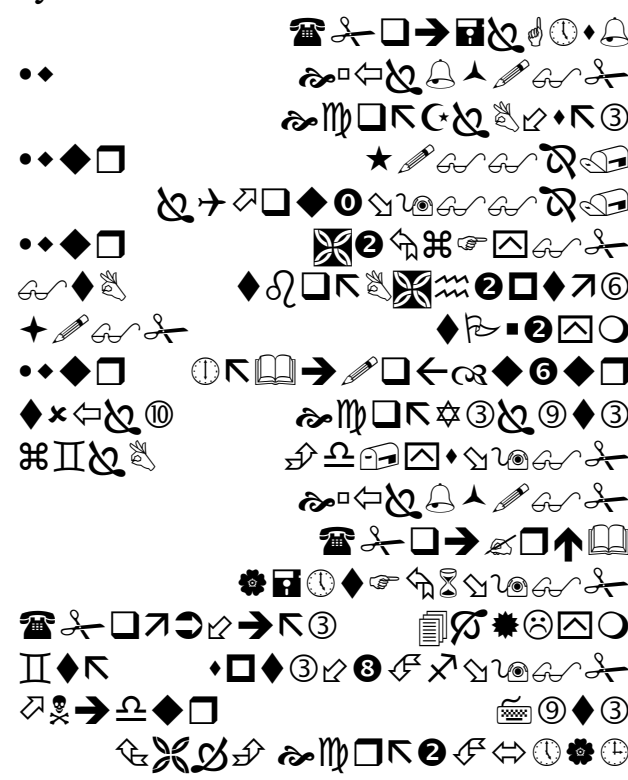

Artinya: "Perangilah orang-orang yang tidak beriman kepada Allah dan tidak pula kepada hari kemudian, dan mereka tidak mengharamkan apa yang telah diharamkan oleh Allah dan RasulNya, dan mereka tidak beragama dengan agama yang benar, yaitu dari orang-orang yang diberikan alKitab kepada mereka (Yahudi dan Nasrani), sehingga mereka membayar jizyah dengan patuh, dan mereka itu orang yang tunduk." (QS. Attaubah/ $9: 29)$.

Jizyah dipungut dari setiap umat, baik mereka ahlul kitab (Yahudi atau Nasarani) atau Majusi dan lainnya, baik itu orang Arab atau Non Arab (menurut pendapat mazhab Imam Maliki, al-'Auza'i dari para ahli fikih dari Syam). as-Syafi'i berpendapat, "Jizyah diterima dari ahlul kitab baik Arab maupun 'ajam (non Arab) termasuk orang Majusi yang menyembah api (ketika itu). Jizyah tidak diterima dari

36 Abdul Aziz Dahlan, Ensiklopedia, hal.852 
penyembah berhala secara muthlak." Abu Hanifah berpendapat, "tidak diterima jizyah dari orang Arab kecuali masuk Islam atau perang". ${ }^{37}$

Sayyid Sabiq mengatakan: "Tujuan jizyah yang dibayarkan dari orang-orang Non muslim yang tinggal di daerah Islam adalah sebagai berikut:

a. Pembagian jizyah sebagai bukti ketundukannya dan bukti bahwa ia tidak menghalangi dan memerangi dakwah kepada agama Allah.

b. Turut andil memberikan belanja pertahanan dirinya, hartanya dan harga dirinya.

c. Turut andil di dalam Baitul maal kaum muslimin untuk menanggung kebutuhan hidup setiap orang yang tidak mampu bekerja." ${ }^{\text {,3 }}$

Amirul Mukminin Umar ibn alKhaththab a tidak memaksakan para Non muslim untuk membayarnya, tetapi mereka diwajibkan membayar jizyah sesuai dengan ketetapan yang telah berlaku dan kemampuan yang dimilikinya.

suatu hari saat Amirul Mukminin Umar ibn al-Khaththab a berkunjung pada suatu tempat dan beliau menjumpai seorang pengemis pria yang buta. Amirul Mukminin Umar ibn al-Khaththab a bertanya kepadanya tentang diri dan keadaan orang tersebut. Orang buta tersebut menjawab kalau dirinya adalah orang Yahudi.

Amirul Mukminin Umar ibn alKhaththab a bertanya kembali tentang keadaan dirinya yang memaksa untuk meminta-minta padahal sudah lanjut usia. Maka dijawab kembali kalau dirinya meminta-minta seperti itu dikarenakan

\footnotetext{
37 M. Abu Ahmad al-Anshory al-Qurthuby, jami'u al-Ahkam al-Qur'an, Beirut: Dar al-Fikr, 1994, juz: 8, hal. 110

38 Sayyid Quttub, Tafsir, hal. 224
}

mempunyai kewajiban terhadap negara untuk membayar jizyah, untuk kebutuhan ekonomi dirumahnya dan karena sudah tidak bisa lagi bekerja disebabkan sudah lanjut usia. Mendengar perkataan orang tersebut, Amirul Mukminin Umar ibn alKhaththab ra memegang tangan kakek tersebut dan membawanya ke tempat kekhilafahan (Istana Amirul Mukminin) dengan memberikan apa saja yang dihajatkan oleh kakek tersebut tanpa memandang agama atau kepercayaan ${ }^{39}$.

Kemudian Amirul Mukminin Umar ibn al-Khaththab a memanggil al-amîn (penjaga Baitul maal) dan berkata: "Buatlah ketetapan dalam hal ini (berikan catatan khusus) untuk orang yang lanjut usia dan orang-orang kafir Dzimmi agar ia tidak meminta-minta".

Al-Qur'an menjelaskan tentang masalah zakat yang harus diberikan kepada orang-orang fakir, miskin atau al-asnāf atsatsamāniyah (delapan golongan yang berhak menerima zakat). Amirul Mukminin Umar ibn al-Khaththab a berpendapat bahwa fakir (al-Fuqārā) berarti orang Islam yang miskin dan tidak mempunyai apa-apa dari hartanya untuk hari esok, kata miskin (al-Masākîn) meliputi keseluruhan orangorang muslim. Dengan begitu umar membebaskan bagi mereka dan menetapkan bantuan untuk mereka dari Baitul maal.

\section{Harta 'Usyr (العشر))}

Secara harfiah 'usyr bemakna sepersepuluh (1/10). ${ }^{40}$ Sedangkan dalam istilah syara 'usyr adalah sesuatu yang diambil oleh negara dari para pedagang yang melewati negaranya. ${ }^{41}$ Menurut

\footnotetext{
39 Muhhammad Husein Haekal, Umar, hal. 13

40 Atabik Ali, Kamus, 1292

41 Muhammad Rawwas Qal'ahji, Ensiklopedi Fiqih Umar ibn Al-Al-Khaththab, hal. 632.
} 
pendapat lain dikatakan bahwa harta 'usyr adalah pajak yang dikenakan atas barangbarang dagangan yang masuk ke negara Islam atau orang yang datang dari negara Islam itu sendiri untuk berdagang. ${ }^{42}$ Diriwayatkan bahwa orang yang pertama kali menetapkan hukum 'usyr dalam Islam adalah Amirul Mukminin Umar ibn alKhaththab $\mathbf{a}^{43}$

Harta 'usyr sudah ada semenjak masa sebelum Islam yang diterapkan oleh orangorang Yunani dan Romawi. Pada masa Rasulullah saw hidup dan khalifah Abu Bakar as-shiddîq 'usyr belum diterapkan, hal itu terjadi karena belum banyaknya orang yang melewati negara Islam dan ekspansi/penyebaran agama Islam belum terlalu jauh. Pada masa Umar ibn alKhaththab a Islam menyebar lebih luas sampai ke semananjung negara luar daerah jazirah Arabia. Sehingga dengan penetapan 'usyr, maka bertambahlah pemasukan harta Baitul maal.

Amirul Mukminin Umar ibn alKhaththab menerapkan 'usyr karena melihat negara-negara luar (selain negara dibawah kekuasaan Umar) mereka menetapkan sepersepuluh kepada setiap orang yang melintasi negaranya. Maka Umar ingin lebih mengetahui berapa jumlah yang diambil oleh negara-negara lain dari pedagang-pedagang muslim yang melintasi negara tersebut untuk berdagang.

Penduduk yang pertama kali dipungut pajak dalam sejarah Islam dari harta 'usyr adalah penduduk Ming dari kaum kafir Harbi, hukum 'usyr bukan bersumber dari al-Qur'an atau al-hadits. Sumbernya merupakan ijtihad Amirul Mukminin Umar ibn al-Khaththab dan kesepakatan para

42 Quthb Ibrahim Muhammad, As-Siyâsah, hal. 33

43 Muhammad Rawwas Qal'ahji, Ensiklopedi Islam, hal. 632 shahabat setelah dimusyawarahkan oleh Umar.

Alasan ditetapkkan hukum 'usyr adalah jika tidak ditetapkan atas dagangan orang kafir dari dagangan mereka yang diambil modalnya, maka harga barang dagangan mereka bisa lebih mahal dibandingkan dengan barang kaum muslimin yang akhirnya akan merugikan kaum muslimin sendiri. Jadi salah satu penyebab Amirul Mukminin Umar ibn alKhaththab menetapkan hukum ijtihadnya, 'usyr harus diterapkan karena orang-orang kafir yang datang ke negera Islam yang tujuannya berdagang kebanyakan diantara mereka melakukan monopoli perdagangan di daerah Islam, apalagi dalam negara Islam terdapat barang yang sama yang dibawa oleh orang kafir Harbi, maka mereka sering meninggikan harga dengan tanpa ada pemeriksaan atau memaksakan orang lain dengan harga yang lebih mahal. Maka ditetapkan 'usyr dengan tujuan agar modal negara bisa kembali sebagai pemasukan harta Baitul maal.

Diantara orang-orang yang diwajibkan untuk membayar harta 'usyr dalam ijtihadnya Amirul Mukminin Umar ibn al-Khaththab adalah semua barang yang dibawa oleh para pedagang saat melewati perbatasan negara baik berupa uang atau berupa barang.yang diperdagangkan.

Ijtihad lainnya yang dilakukan Amirul Mukminin Umar ibn al-Khaththab selama menjabat sebagai kepala negara adalah membedakan pengambilan harta 'usyr dari orang Islam, kafir Dzimmi dan pedagang yang ikut memerangi orang Islam. Harta 'usyr diberlakukan untuk kafir Dzimmi dan tidak untuk kafir Harbi, alasannya adalah karena orang-orang Dzimmi mendapatkan perlindungan dari orang Muslim. Sedangkan untuk kafir Harbi sangat sulit 
untuk diambil baik 'usyr maupun harta jizyah.

Anggaran pendapatan yang dimasukan Umar ke dalam kas negara yang disebut dengan Baitul maal yaitu harta ghanimah, harta $f a ' i$, harta kharaj, harta jizyah dan harta 'usyr. Adapun tentang zakat sebagai pemasukan aggaran negara terbesar pada masa Amirul Mukminin Umar ibn Al-Khaththab. Penjelasan zakat sudah banyak dan kiranya cukup tidak dijelaskan kembali dalam tesis ini.

\section{Pendistribusian Harta Baitul Maal}

Setelah pembahasan tentang pendapatan negara pada masa Amirul Mukminin, bahasan selanjutnya tentang bagaimana pendapatan itu dapat didistribusikan dengan baik dan benar sesuai hukum, pendistribusian itu diberikan kepada mereka yang berhak mendapatkannya, penentuan diantara masyarakat muslim yang berhak mendapatkan harta tersebut dari Baitul maal dan bagaimana Umar memberikan fatwanya dalam pendistribusian harta kepada para shahabat senior dan para tentara Islam.

Menurut Jamil Ahmad pendapatan persemakmuran pada masa Amirul Mukminin Umar ibn al-Khaththab berasal dari sumber:

1. Zakat atau pajak yang dikenakan secara bertahap terhadap muslim yang berharta.

2. Kharaj atau pajak bumi.

3. Jizyah atau pajak perseorangan. ${ }^{44}$

Dalam pendapat lain dikatakan bahwa Pendapatan yang diterima dari

44 Jamil Ahmad, seribu Muslim Terkemuka, Jakarta: Pustaka Fidaus, 2003, cet.III, hal. 33
Baitul maal terbagi ke dalam empat bagian berikut: ${ }^{45}$

1. Pendapatan yang diperoleh dari zakat dan harta 'usyr yang dikenakan terhadap muslim.

2. Pendapatan yang diperoleh dari khumus dan shadakah

3. Pendapatan yang diperoleh dari kharaj, fai dan jizyah 'usyr dan sewa tetap tahunan.

4. Berbagai macam pendapatan yang diterima dari semua sumber.

Dalam pendistribusiannya Amirul Mukminin Umar Ibn al-Khaththab a merupakan penguasa yang tangguh dan secara efektif mampu menjaga perbedaan harta secara wajar serta dalam batas-batas yang seimbang. ${ }^{46}$

Dari kedua pendapat di atas dapat diambil kesimpulan, harta yang didistribusikan kepada kaum muslimin dari dalam Baitul maal yaitu zakat, kharaj, jizyah, fa'i, khumus dan berbagai macam pendapatan yang masuk ke dalam kas negara sebagai anggaran pendapatan.

Dalam pendistribusian terhadap harta ghanîmah, Amirul Mukminin Umar ibn alKhaththab merupakan penguasa yang tangguh dan secara efektif mampu menjaga perbedaan harta secara wajar serta dalam batas-batas yang seimbang. ${ }^{47}$

Sebagian Ulama Fiqih mengatakan: "Amirul Mukminin Umar Ibn al-Khaththab membagi-bagikan harta rampasan (ghanîmah), seperlima dari harta harta rampasan tersebut dibagikan kepada tiga golongan yaitu bagian orang-orang miskin,

45 Adiwarman Azwar Karim, Sejarah Pemikiran Ekonomi Islam, The International Institute Islamic Thought (IIIT), Jakarta, 2001, hal. 53

46 Afzalur Rahman, Doktirn Ekonomi Islam, Jakarta: PT Bani Bhakti Wakaf, 2003, hal. 163

47 Afzalur Rahman, Doktrin Ekonomi Islam, hal. 163 
Yatama, dan bagian Ibnu Sabil". Di lain sisi dikatakan bahwa: "Amirul Mukminin Umar Ibn al-Khaththab menulis surat kepada Ammar Ibn Yassir dan Thariq Ibn Syihab al-Ahmasi. Dalam suratnya dikatakan bahwa "harta rampasan itu hanya untuk orang-orang yang ikut berperang. Karena itu orang-orang yang baru datang dan setelah perang usai, maka tidak berhak mendapatkan apa-apa dari harta ghanîmah atau al-anfâl". 48

Menurut Imam Syafi'i pendistribusian harta $f a{ }^{\prime} i$ dibagi ke dalam 5 bagian; 4 diantaranya adalah untuk Nabi saw dan lima dari sisanya diberikan untuk lima bagian dan satu bagian terakhir untuk Rasulullah saw. Satu bagian untuk kerabat Rasul (Bani Hasyim dan Bani Muthallib) karena mereka tidak berhak mendapatkan harta Zakat dan shadaqoh, dengan demikian dalam harta $f a$ ' $i$ semua kerabat Rasulullah berhak dan diperbolehkan mengkonsumsinya. Satu bagian lainnya adalah untuk Yatâmã, satu bagian untuk Masâkĩn, satu bagian untuk Ibn Sabĩl. ${ }^{49}$

Amirul Mukminin Umar Ibn alKhaththab a seorang khalifah yang adil. Keadilan beliau dipercaya dan telah dibicarakan baik oleh mereka yang beragama Islam atau Non muslim, bahkan orientalis barat-pun mengatakan bahwa Amirul Mukminin Umar Ibn al-Khaththab a adalah orang yang terpercaya dan 'adil dalam pemerintahannya. Ketelitian yang ada pada jiwa Amirul Mukminin Umar Ibn al-Khaththab a dalam penditribusian harta Baitul maal sebagai seorang pemimpin, Umar tidak berani mengambil atau membelanjakan harta Baitul maal kecuali

\footnotetext{
48 M. Rawwas Qal-Haji, Ensiklopedi Fikih Umar ibn al-Al-Khaththab, (terjmh. Muhammad Abdul Mujib), hal. 86

49 Al-Qurthubi, Jilid 18, hal. 12
}

setelah ada kesepakatan dari shahabat lainnya.

Dari Abu Umamah ibn Sahl ibn Unaif $\mathbf{a}$, dia berkata :

"Dalam kurun waktu yang lama Amirul Mukminin Umar Ibn alKhaththab a tidak mengambil makanan atau harta lainnya dari pemasukan harta Baitul maal. Pernah terjadi pada masa sulit (paceklik), Umar meminta pendapat kepada para shahabat Rasulullah yang lain tentang pengambilan harta dari Baitul maal".

Umar berkata: "Saya telah menyibukan diri dengan urusan kekhilafahan ini, lalu apakah saya boleh mengambil harta dari Baitul maal?", Ali ibn Abi Thallib a berkata : "Anda boleh mengambil makanan untuk makan siang dan malam anda secukupnya", lalu Amirul Mukminin Umar Ibn al-Khaththab a mengambil sebagaimana yang disarankan oleh shahabatnya itu. ${ }^{50}$

Sikap Amirul Mukminin Umar Ibn alKhaththab a merupakan sikap yang sangat mulia, Umar merupakan salah seorang Amirul Mukminin diantara para Khalifah yang teliti dalam pengambilan uang atau harta milik umat. Dengan kejadian seperti ini hidup Umar lebih terjaga dari rongrongan musuh dan orang yang membencinya.

Begitulah sikap Amirul Mukminin Umar Ibn al-Khaththab a yang bertanggung jawab dengan amanat yang diembannya, Karena dalam prinsip Islam jabatan merupakan amanah yang akan dan harus dipertanggung jawabkan pada hari kiamat kelak.

Ibnu Sa'ad dan Sa'id ibn Manshur serta yang lainnya meriwayatkan dari jalur

50 Imam Sayuthi, Attarikh al-Khulafa, Dar al-
Kutub al-Ilmiyyah, hal. 163 
yang beragam dari Umar bahwa Umar berkata:

\begin{abstract}
"Sesungguhnya saya memposisikan diri terhadap harta Allah laksana posisi seorang wali terhadap anak yatim dalam hartanya. Jika saya mampu, maka saya akan menahan diri dari memakan harta Allah itu (harta Baitul maal) dan jika saya tidak mampu (fakir) maka saya akan membayar kembali apa yang saya makan ini. ",51
\end{abstract}

Ini merupakan ucapan dan amanah Amirul Mukminin Umar ibn al-Khaththab a dalam pendistribusian harta, Umar tidak akan memakan hak milik orang lain yang bukan haknya. Umar sangat menjaga amanat tersebut walaupun terhadap harta orang lain, Umar tidak akan menahan atau mensuplainya sendiri. Jika harta tersebut tidak ada dan Umar belum mampu memberikannya, maka akan meminjam harta orang lain untuk diberikan kepada orang yang lebih membutuhkan atau yang datang kepadanya dengan meminta-minta dan Umar sendiri yang akan menggantikan harta pinjaman tersebut.

Pada suatu hari Amirul Mukminin Umar ibn al-Khaththab jatuh sakit, dokter memberikan resep supaya minum madu. Sebenarnya banyak madu yang tersimpan dalam Baitul maal. Tetapi karena amanah dan kehati-hatiannya terhadap harta umat, Umar tidak berani untuk mengambilnya walaupun hanya satu tetes, kecuali setelah adanya ijin dari dewan rakyat. ${ }^{52}$

Khalifah menaruh perhatian sangat besar dalam usaha perbaikan keuangan negara dengan menempatkannya pada jalur yang sehat. Umar membentuk diwān (departemen keuangan) yang dipercayakan

\footnotetext{
51 Ibid., hal. 160

52 Jamil Ahmad, Seribu, hal. 38
}

menjalankan administrasi pendapatan negara $^{53}$.

Masalah Baitul maal yang merupakan perbendaharaan negara, dipisahkan antara harta negara untuk kepala negara dan milik pribadi hasil kerja Umar. Dalam hukum syara' ditetapkan bahwa harta Baitul maal mempunyai hak berdiri sendiri, mengendalikan harta rakyat, dapat memiliki dan dapat dimiliki, dapat menerima tarikah orang yang meninggal yang tidak ada warisannya (ahli waris), ataupun menerima wasiat dan dapat pula bertindak sebagai penggugat atau tergugat. ${ }^{54}$

Semuanya ini dilakukan oleh al-amîn Baitul maal atau disebut juga dengan al-shâhib Baitul maal sebagai orang yang dipercaya dan orang yang berada di bawah pengawasan Amirul Mukminin. Kepala negara tidak mempunyai hak dari Baitul maal selain dari sekedar yang diperlukan untuk nafkah keluarganya.

\section{E. Daftar Pustaka}

Al-Maududi, Abu A'la, the Islamic Movemen: The Dynamics of Values, Power and Change. Leicestyer .U.K: The Islamic Poundation

Al-Zuahayly, Wahbah, al-Fiqh al-Islamy Adilatuh, (terjmah:Agus Effendi) Bandung, PT. Remaja Rosdakarya, 2000, cet. V

Ash-shiddieqy, T.M Hasbi, Pengantar Fiqih Mu'malah, Jakarta: PT. Bulan Bintang, 1989, cet. III

Aziz al-Halawi, Muhammad Abdul, alFatawa wa al-'Aqidah Amirul Mukminin Umar ibn al-Khaththab a , (terjmh. Zubeir Suryadi Abdullah) 2003, Surabaya, Risalah Gusti, cet II

Baltaji, Muhammad, al-Manhaj li Umar ibn al-Al-Khaththab fi at-Tasyri',

\footnotetext{
53 Ibid., hal. 33

54 T. M Hasbi Ash-shiddieqy, Pengantar Fiqih Mu'malah, Jakarta: PT. Bulan Bintang, 1989, cet. III, hal. 184.
} 
(terjmh. Masturi Ilha), Khalifa, Jakarta, 2005

Dahlan, Abdul Aziz, Ensiklopedia Hukum Islam, Jakarta, PT Intermasa, 1996.

Departemen Agama R.I, Proyek pengadaan kitab Suci al-Qur'an, Jakarta, 1983/1984 hal.61

Farook, Khussed Ahmad, Hazrat Umar ke Sarkari, Nadwatul Musanifeen, Delhi

Imam Taqiyuddin Abi Bakar bin Muhammad al-Husaini, Kifayatu alAkhyar fi Halli Ghayati al-Ikhtisor, Darul al-Kutub, Surabaya, Juz II

Jaribah bin Ahmad al-Haritsi, al-Fiqh alIqtishâdi li Amiri al-Mukminîn Umar ibn al-al-Khaththab, (terjmh.Asmuni Solihan Zmakhsari), Jakarta: Khalifa, 2006

Karim, Adiwarman Azwar, Sejarah Pemikiran Ekonomi Islam, The International Institute Islamic Thought (IIIT), Jakarta, 2001

M. Abu Ahmad al-Anshory al-Qurthuby, jami'u al-Ahkam al-Qur'an, Beirut: Dar al-Fikr, 1994, juz: 8

Pamungkas,Isma'il, Seri Riwayat Nabi, Bandung: PT Remaja Rosda Karya, 2000

Qal'ahji, Muhammad, Mausu'atu al-Fiqhu Umar Ibn Al-Al-Khaththab, (terjmh: M. Abdul Mujib), PT Jakarta, Raja Grafindo Persada, 1999

Quttub, Sayyid, Tafsir Fi Zilal Qur'an, (terjm. As'ad Yasin dkk) Jakarta: Gema Husni, 2004

Ra'ana, Irfan Mahmud, Economic System Under Umar Greath(terjmh, Mansuruddyn Djoely), Pustaka Firdaus, Jakarta, 1997, hal.118

Yunus, Mahmud, Kamus Arab Indonesia, Jakrta, PT. Hida Karya Agung, 1990 